\title{
Relationship between visual field changes and optical coherence tomography measurements in advanced open-angle glaucoma
}

\author{
Snezhina S. Kostianeva ${ }^{1,2}$, Marieta I. Konareva-Kostianeva ${ }^{1,2}$, Marin A. Atanassov ${ }^{1,2}$ \\ ${ }^{1}$ Department of Ophthalmology, Faculty of Medicine, Medical University of Plovdiv, Plovdiv, Bulgaria \\ ${ }^{2}$ Clinic of Ophthalmology, St. George University Hospital, Plovdiv, Bulgaria
}

Correspondence: S. Kostianeva, Ph.D. student and resident, Department of Ophthalmology, Faculty of Medicine, Medical University of Plovdiv, Plovdiv, 15A Vassil Aprilov Blvd., 4002, Plovdiv, Bulgaria

E-mail: snezhina_sk@abv.bg

Tel.: +359882253337

Received: 27 March 2016

Accepted: 5 July 2016

Published Online: 8 Aug 2016

Published: 30 Sep 2016

Key words: open-angle glaucoma, visual field, optical coherence tomography

Citation: Kostianeva SS, Konareva-Kostianeva Ml, Atanassov MA. Relationship between visual field changes and optical coherence tomography measurements in advanced open-angle glaucoma. Folia Medica 2016;58(3);174-181 doi: 10.1515/folmed-2016-0027

\begin{abstract}
Aim: To assess relationships between functional changes in visual field and structural changes in advanced open-angle glaucoma (OAG) found using spectral-domain optical coherence tomography (SD-OCT).

Methods: Thirty-one eyes of 25 patients with OAG were included in this study. Besides the routine ophthalmological exam the patients underwent standard automated perimetry (SAP) (Humphrey Field Analyzer) and SD-OCT (RTVue-100) performed within 6 months. The global perimetric indices in the study group were as follows: mean deviation (MD) $12.33 \pm 6.18 \mathrm{~dB}$ and pattern standard deviation (PSD) $9.17 \pm 3.41 \mathrm{~dB}$. The relationship between OCT measurements and MD and PSD was evaluated by correlation analysis (Pearson's correlation coefficient) and regression analysis (linear and nonlinear regression models).
\end{abstract}

Results: Thickness measurements of the lower halves of ganglion cell complex (GCC) and retinal nerve fiber layer by two scanning protocols (ONH and 3.45) showed these to be thinner than the upper halves, but the difference failed to reach statistical significance. The correlations between global indices MD/PSD and most of the analysed quantitative OCT measurements were moderate ( $r$ in the range between 0.3 and 0.6). The correlation between MD and GCC showed nonlinear cubic regression $\left(R^{2}=0.417, P=0.004\right)$. Good correlation was found between MD and GLV $\left(R^{2}=0.383 ; P=0.008\right)$. Linear regression $(P<0.05)$ was found only between MD and Cup area $\left(R^{2}=0.175, P=0.024\right)$ and between MD and RNFL by 3.45 protocol $\left(R^{2}=0.131, P=0.045\right)$.

Conclusion: Nonlinear regressive models appear to be more appropriate in the assessment of the correlations between functional and structural changes in eyes with advanced glaucoma. The correlations we found were moderate.

\section{INTRODUCTION}

Glaucoma is a multifactorial optic neuropathy characterized by structural damages of the optic nerve head and functional visual deficit. As glaucoma progresses the structural and functional changes increase. They are associated with loss of retinal ganglion cells (RGCs) and their axons (retinal nerve fiber layer, RNFL).${ }^{1-5}$ Currently, functional measurements are done using standard automated perimetry (SAP) which remains the gold standard for diagnosis and monitoring of glaucomatous neuropathy. The recently developed high-tech imaging methods such as optical coherence tomography (OCT) have gained a very high diagnostic value in assessing structural changes occurring in glaucoma. OCT is characterised with high accuracy in assessing the glaucomatous defects manifested as peripapillary RNFL thinning and macular inner retina thinning. ${ }^{6-9}$ There is a close relationship between structural and functional damage in glaucoma - it can be assumed that they are strongly correlated. ${ }^{4,10,11}$ However, many factors affect the relationship and limit direct comparison of the sensitivity of SAP (reflecting the functional losses) and OCT measurements (RNFL thickness and the inner macula thickness) (reflecting structural changes). Firstly, the computed perimeter and optical coherence tomography have different scales of measurement: SAP measures visual sensitivity in $\log$ units (range $4 \log$ units) ${ }^{12}$, while OCT measures the thickness of RNFL and macula inner layers in 
microns (in the linear range from 25 to $200 \mathrm{mi}-$ crons in normal subjects ${ }^{13-15}$ ). Secondly, when SAP macular threshold is compared with local defects in RNFL / inner retina an adaptation is required to the so-called topographic map. The peripapillary and macular areas corresponds to very specific areas of the perimetric test. ${ }^{12-19}$ A discrepancy has been found by some researchers between perimetric losses and OCT changes as glaucoma progresses. The two approaches to assess the glaucoma process do not run parallel. ${ }^{16,20,21}$ There are few studies that can confirm the exact nature of the structural / functional relationship in glaucoma using regression models.

\section{AIM}

To assess the relationship of functional visual field changes and structural changes in advanced (moderate / severe) open-angle glaucoma (OAG) using spectral-domain optical coherence tomography (SD-OCT)

\section{METHODS}

The study included 31 eyes with advanced OAG of 25 patients with mean age $63.1 \pm 10.9$ years. Visual field (VF) testing was performed using Humphrey Field analyzer (Carl Zeiss Meditec, Dublin, CA), programme $30-2$. The test was considered reliable when fixation losses were less than $20 \%$ and false positive and false negative errors were less than $15 \%$. The mean value of the visual field sensitivity is calculated by the software of the machine and presented as mean deviation (MD), pattern standard deviation (PSD) and VF index (VFI). Visual field defect is defined as 3 or more adjacent points of depression, which can be observed with a probability of $\mathrm{P}<0.05$ in a normal population and at least one of them is with a probability of $\mathrm{P}<0.01$. All depressed points are located on one side of the horizontal meridian in print "pattern deviation plot" and classified outside the normal range (outside normal limits). The defects must be confirmed in at least two visual field tests. Moderate glaucoma was defined as VF loss with an MD between -6 and $12 \mathrm{~dB}$, and severe glaucoma as an MD worse than $-12 \mathrm{~dB}$.

In the present study the examined eyes had $\mathrm{MD}-12.33 \pm 6.18 \mathrm{~dB}$ (mean $\pm \mathrm{SD}$ ), and PSD $9.17 \pm 3.41 \mathrm{~dB}$.

These same eyes were tested by SD-OCT within six months. We used RTVue-100 (v. 4.0.5.39, Optovue). It takes $26000 \mathrm{~A}$-scans per second achieving a $5 \mu \mathrm{m}$ resolution into tissue. The peripapillary
RNFL, GCC and optic disc parameters were measured. RNFL thickness was calculated using two modes: ONH mode and 3.45 mode. In the $\mathrm{ONH}$ mode RNFL thickness is recalculated from the "en face" imaging obtained by six circular and 12 linear incoming measurements. In our study we measure and compare the following parameters from this program: the mean thickness of the peripapillary RNFL (RNFL1 Ave), the RNFL thickness of the upper half (RNFL1 Sup) and the RNFL thickness of the lower half (RNFL1 Inf). The RNFL thickness in 3.45 mode (RNFL2) is measured along a $3.45-\mathrm{mm}$-diameter circle around the optic disc. The following parameters from this programme were selected for the statistical analysis: the mean thickness (RNFL2 Overall), the RNFL thickness of the upper half (RNFL2 Sup), the RNFL thickness of the lower half (RNFL2 Inf) and the RNFL thickness of the four quadrants - temporal, superior, nasal and lower (RNFL2 temporal quadrant, RNFL2 superior quadrant, RNFL2 nasal quadrant, RNFL2 inferior quadrant). The parameters of the optic disc were defined in the $\mathrm{ONH}$ mode. The major parameters of the optic disc (disc area, cup area, rim area, rim volume, cup disc area ratio, cup disc horizontal ratio, cup disc vertical ratio) were analysed and compared. The GCC scan was centered $1 \mathrm{~mm}$ temporal to the fovea and covered a square grid of 7 by $7 \mathrm{~mm}$ of the central macula. The GCC thickness was measured from the internal limiting membrane to the outer inner plexiform layer boundary. The average GCC thickness (GCC Ave), the average thickness of the upper GCC (GCC Sup) and the average thickness of the lower GCC (Inf GCC) were calculated. Two other diagnostic GCC parameter - focal loss volume (FLV) and global loss volume (GLV) were compared with the perimeter indices. GLV and FLV are pattern-based parameters that reflect different aspects of losses in the GCC. They summarize the volume of the losses in the inner macula with different focus levels. ${ }^{23}$ FLV represents the integral of the deviation in areas with significant focal losses. GLV is calculated as the sum of negative deviations in the whole area.

We excluded images with a signal strength index (SSI) of less than 35. The measured data were also excluded if they were noncompliant with the algorithm of the detection surface or when there was decentration of the circular area. The relationship between OCT measurements and global indexes MD and PSD was determined using the following statistical analyses: correlation analysis 
(Pearson's correlation coefficient) and regression analysis(linear and nonlinear regression models).

\section{RESULTS}

Table 1 shows the average GCC, RNFL1 and pRNFL2 in the upper and lower half of the scanned areas.

Our results show that GCC inf $<$ GCC sup, RNFL inf $<$ RNFL sup, RNFL2 inf $<$ RNFL2 sup, but the differences failed to reach significance. The lower halves of the GCC, RNFL1, RNFL2 were thinner than the upper halves. The RNFL thicknesses measured in RNFL 3.45 mode showed lower values than the RNFL thicknesses measured in $\mathrm{ONH}$ mode and the difference was significant

Table 1. Average GCC and pRNFL in upper and lower half

\begin{tabular}{lc}
\hline OCT Parameters & $\begin{array}{c}\text { Thickness (MM) } \\
\text { (Mean } \pm \text { SD) }\end{array}$ \\
\hline GCC Sup & $80.20 \pm 21.95$ \\
GCC Inf & $76.75 \pm 17.84$ \\
RNFL1 Sup & $78.34 \pm 17.64$ \\
RNFL1 Inf & $77.63 \pm 17.64$ \\
RNFL2 Sup & $73.87 \pm 14.60$ \\
RNFL2 Inf & $72.29 \pm 15.55$ \\
\hline
\end{tabular}

Table 2. Pearson correlations with significance between perimetric index MD and some OCT parameters

\begin{tabular}{cll}
\hline $\begin{array}{c}\text { Perimetric } \\
\text { indices }\end{array}$ & OCT Parameter & $\begin{array}{c}\text { Correlation } \\
\text { coefficient }\end{array}$ \\
\hline \multirow{2}{*}{ MD } & GCC Ave & $\mathrm{R}=0.453$ \\
& & $\mathrm{P}=0.015$ \\
MD & GLV & $\mathrm{R}=-0.539$ \\
& & $\mathrm{P}=0.003$ \\
MD & RNFL2 & $\mathrm{R}=0.363$ \\
& & $\mathrm{P}=0.045$ \\
MD & RNFL2 Sup & $\mathrm{R}=0.480$ \\
& RNFL2 temporal & $\mathrm{P}=0.006$ \\
MD & quadrant & $\mathrm{P}=0.412$ \\
& RNFL2 upper & $\mathrm{R}=0.021$ \\
MD & quadrant & $\mathrm{P}=0.014$ \\
\hline
\end{tabular}

$(\mathrm{P}=0.009)$.

We observed a significant correlations with medium strength $(\mathrm{R}<0.6)$ between $\mathrm{MD}$ and OCT parameters (Pearson correlation). The correlation coefficient $\mathrm{R}$ (with $\mathrm{P}<0.05)$ is presented in Table 2 .

PSD correlated statistically significantly only with the upper half of RNFL2 (protocol RNFL 3.45).

The statistically significant correlations of $\mathrm{MD}$ and some optic disc parameters were also of moderate degree (Table 3).

Table 3. Correlations of MD with some OCT optic disc parameters

\begin{tabular}{cll}
\hline $\begin{array}{c}\text { Perimetric } \\
\text { indices }\end{array}$ & OCT indicator & $\begin{array}{c}\text { Correlation } \\
\text { coefficient }\end{array}$ \\
\hline \multirow{2}{*}{ MD } & Cup Area & $\begin{array}{l}\mathrm{R}=-0.419 \\
\mathrm{P}=0.024\end{array}$ \\
$\mathrm{MD}$ & Rim Area & $\mathrm{R}=0.421$ \\
& & $\mathrm{P}=0.023$ \\
$\mathrm{MD}$ & Rim Volume & $\mathrm{R}=0.387$ \\
& & $\mathrm{P}=0.038$ \\
$\mathrm{MD}$ & Cup Disc Area & $\mathrm{R}=-0.447$ \\
& Ratio & $\mathrm{P}=0.015$ \\
$\mathrm{MD}$ & Cup Disc Vert. & $\mathrm{R}=0.442$ \\
& Ratio & $\mathrm{P}=0.016$ \\
\hline
\end{tabular}

In the study we tried to find the regression models that might show, statistically significantly, what the correlation of MD with the structural changes (OCT parameters) is. The association between MD and GCC Ave showed nonlinear regression: cubic $\left(\mathrm{R}^{2}\right.$ $=0.417, \mathrm{P}=0.004)$ and quadratic $\left(\mathrm{R}^{2}=0.358\right.$, $\mathrm{P}=0.004)$ (Fig. 1).

The nonlinear model (cubic regression) corresponded to the relationship between MD and the hemispheres of the GCC (upper half: $\mathrm{R}^{2}=0.374$; $\mathrm{P}$ $=0.05$, lower half $\left.\mathrm{R}^{2}=0.270 ; \mathrm{P}=0.034\right)$ (Fig. 2).

The best correlation between MD and GLV was nonlinear: (quadratic: $\mathrm{R}^{2}=0.368, \mathrm{P}=0.003$; cubic: $\mathrm{R}^{2}=0.383, \mathrm{P}=0.008$ ) (Fig. 3).

The regression models observed between $\mathrm{MD}$ and RNFL 2 Sup were linear $\left(\mathrm{R}^{2}=0.230, \mathrm{P}=0.06\right)$ and quadratic $\left(\mathrm{R}^{2}=0.260, \mathrm{P}=0.015\right)$ (Fig. 4).

Nonlinear model (quadratic and cubic regression) corresponded to the relationship between $\mathrm{MD}$ and Cup Disc Area Ratio: quadratic $\left(\mathrm{R}^{2}=\right.$ $0.301, \mathrm{P}=0.010)$; cubic $\left(\mathrm{R}^{2}=0.318, \mathrm{P}=0.021\right)$ (Fig. 5).

Nonlinear regression was observed in the relationship between MD and Cup disc vertical Ratio (quadratic $\mathrm{R}^{2}=0.292, \mathrm{P}=0.011$ ) (Fig. 6).

Nonlinear (quadratic) regression was observed 

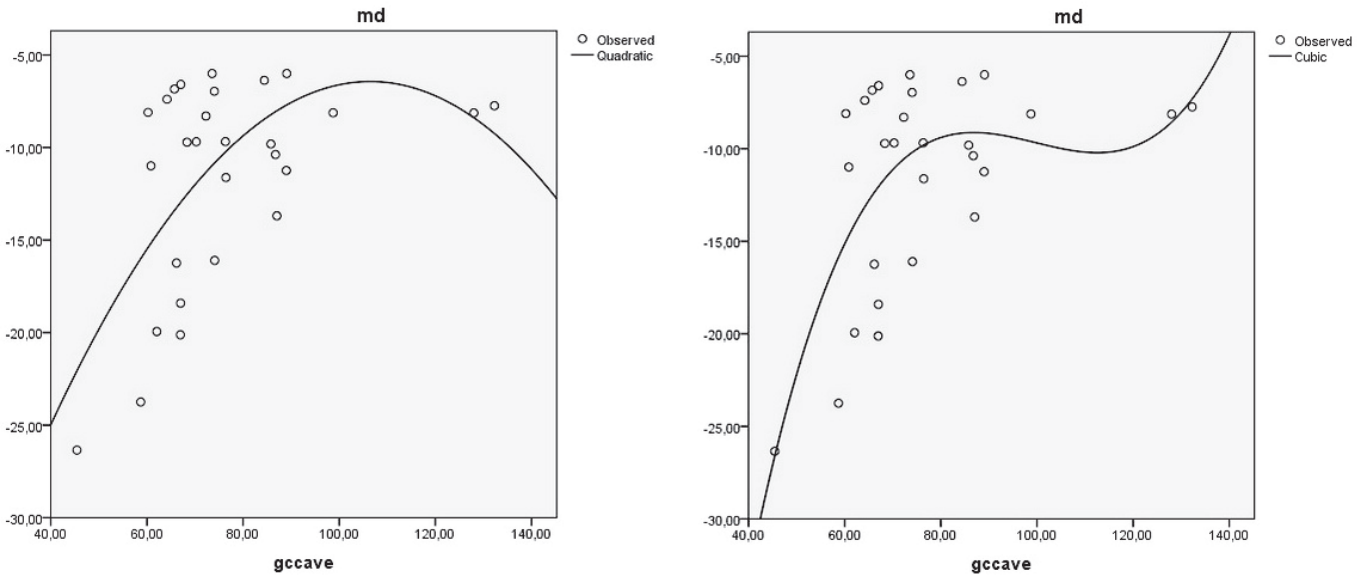

Figure 1. Nonlinear regression model of the relationship between MD and GCC Ave.
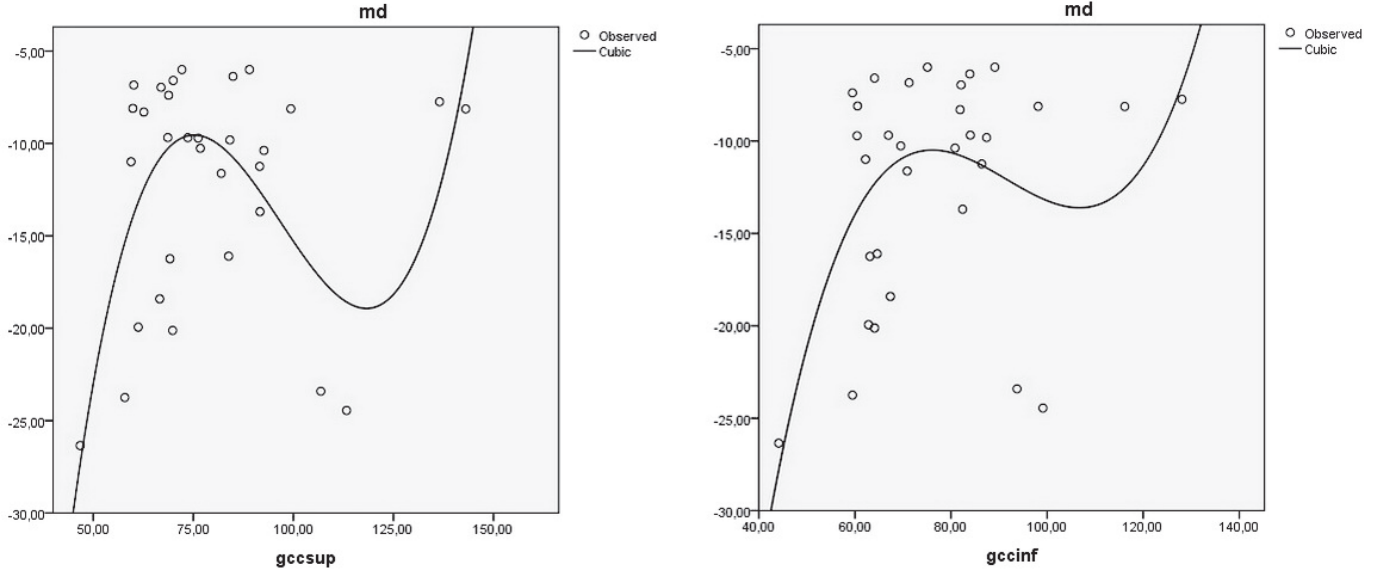

Figure 2. Nonlinear regression model of the relationship between MD and the GCC hemispheres.
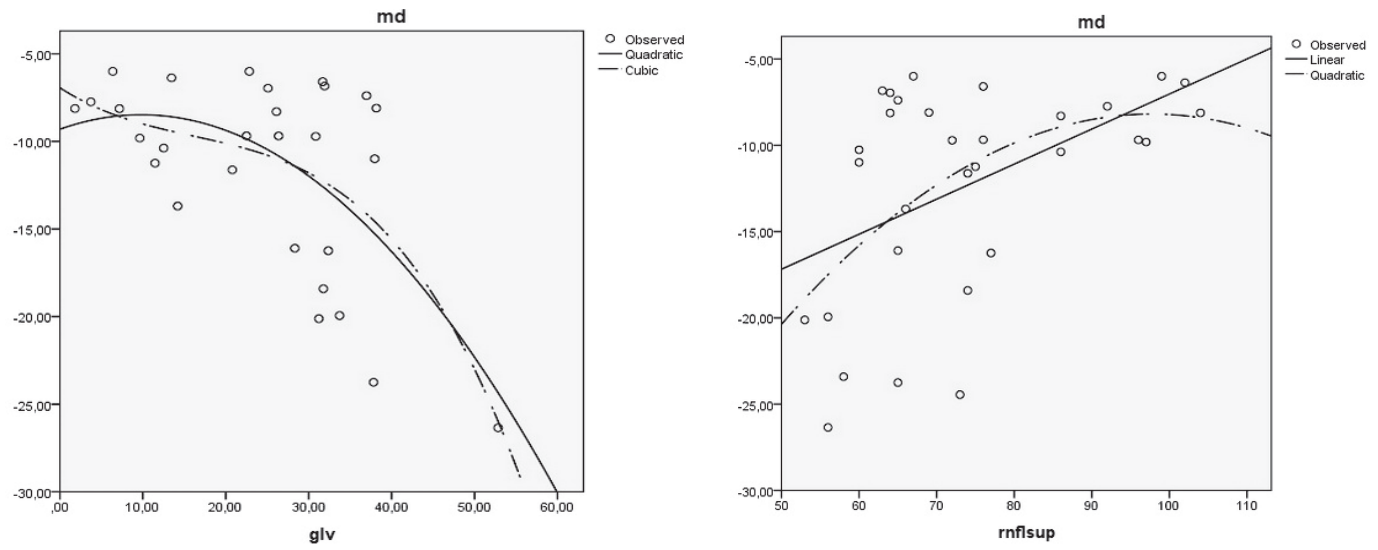

in the association MD / Rim Area $\left(\mathrm{R}^{2}=0.228, \mathrm{P}\right.$ $=0.035)$ (Fig. 7).

All three regression models covered the correlation between MD and Cup Area (Fig. 8).

Linear regression was found only in the relationship between MD and RNFL $2\left(\mathrm{R}^{2}=0.131\right.$,
Figure 3. Nonlinear regression model of the relationship between MD and GLV.
Figure 4. Regression models for the relationship between MD and RNFL 2 Sup.

$\mathrm{P}=0.045)$ (Fig. 9).

\section{DISCUSSION}

The results of this study suggest that the structural changes in glaucoma do not occur in parallel with the functional changes of the disease. Comparing 


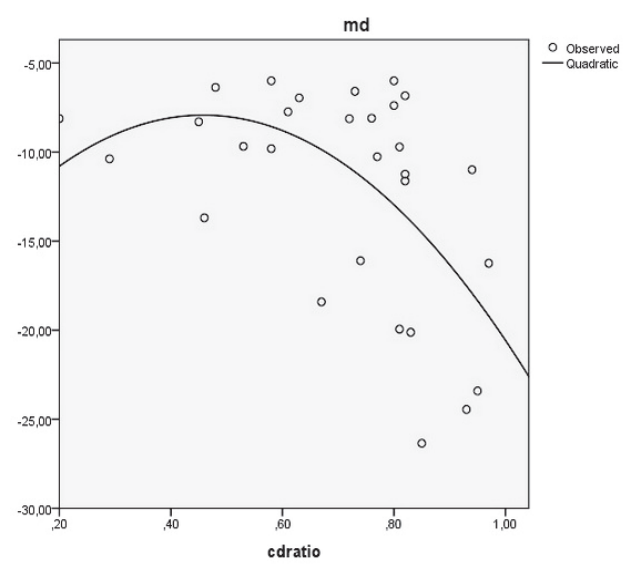

Figure 5. Nonlinear regression model for the relationship between MD and Cup Disc area ratio.

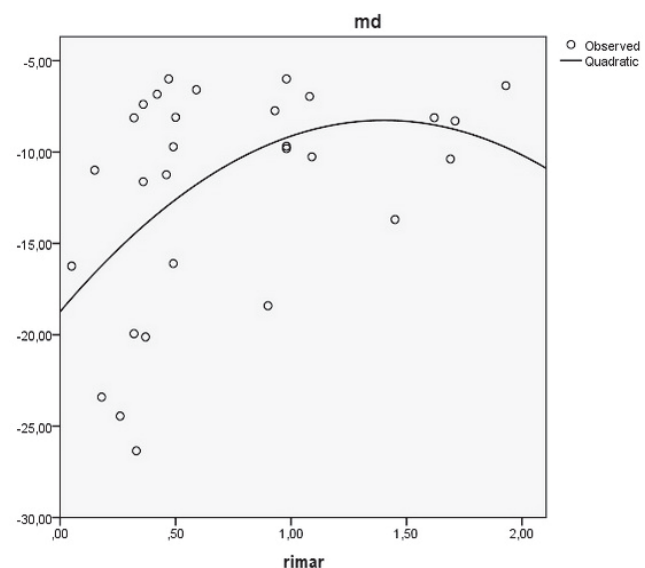

Figure 7. Nonlinear regression model for the relationship between MD and Rim Area.

the two methods (SAP and OCT) for advanced glaucoma we found a discrepancy between structural damage and functional deficits as they occur in the course of the disease.

$\mathrm{Na}$ Rae Kim et al. have shown that the GCC thickness is somewhat a lesser indicator than the peripapillary RNFL thickness in severe glaucoma. ${ }^{22}$ This can be accounted for by the fact that only $50 \%$ of RGCs are present in the macula verses almost $100 \%$ of these in peripapillary RNFL. Although RTVue covers a relatively large macular area (7 by $7 \mathrm{~mm}$ ), the OCT macula test cannot assess the entire ganglion cells layer. In moderate and severe stages of glaucoma there is already an extensive GCC loss and/or extreme peripheral ganglion cells losses. This can limit the diagnostic value of the GCC in advanced glaucoma. ${ }^{22}$

$\mathrm{Na}$ Rae Kim et al. have found that the peripapillary RNFL thickness and the GCC thickness have similar structural and functional relationship

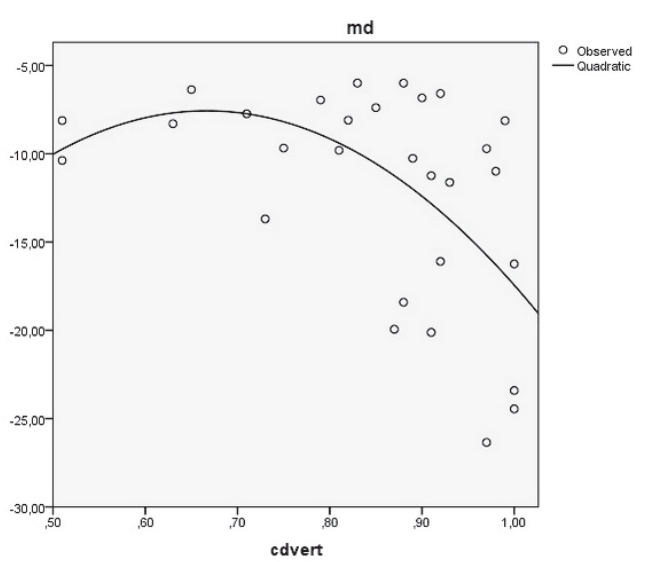

Figure 6. Nonlinear regression model of the relationship between MD and Cup Disc vertical ratio.

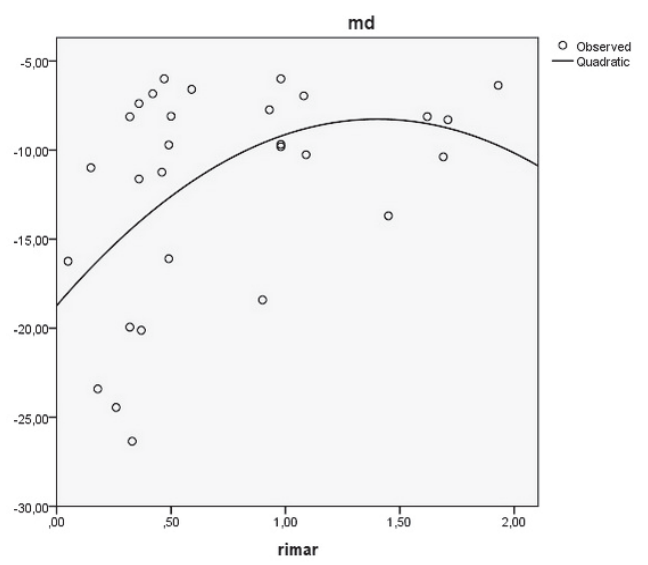

Figure 8. Regression models for the relationship between MD and Cup Area.

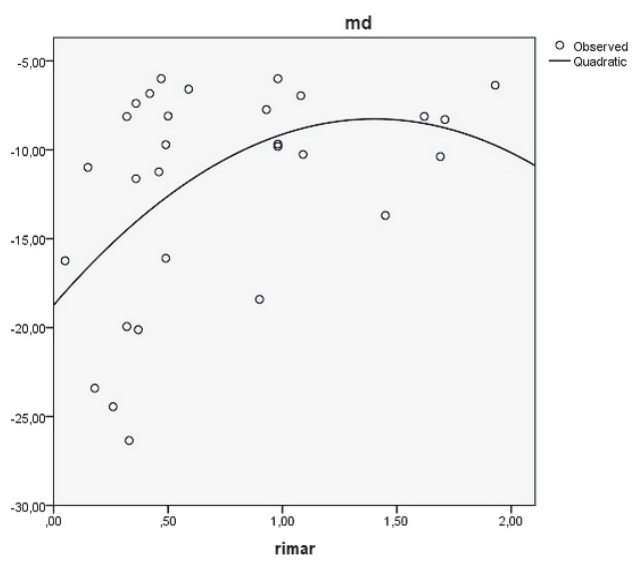

Figure 9. Linear regression model for the relationship between MD and RNFL 2.

with the sensitivity of the visual field. The GCC parameters (FLV, GLV, GCC average, GCC thickness of the upper and lower halves) clearly identify glaucoma with the early, moderate and heavy losses in the visual field. ${ }^{22}$ 
Regression analysis is the most common and effective method of investigating the correlation between structure and function in the course of glaucoma process. ${ }^{24}$ Some researchers consider the quantitative regression models as the most suitable methods to find correlations of SAP and RNFL measurements by OCT. ${ }^{16,25-31}$ It is assumed in these methods that some sections of SAP are associated with RNFL measurements linearly, while others show nonlinear association. For example, areas with zero sensitivity correspond to unchanging residual RNFL thickness. ${ }^{25-27}$ Nonlinear models assume that the nonaxonal components of the RNFL thickness increase with age and as glaucoma progresses. This increase in advanced glaucoma affects the overall thickness of RNFL. ${ }^{32}$

There are supporters also for the linear models for relationship between SAP and OCT-parameters in glaucoma that may be found in the literature but these base their conclusions on different assumptions. ${ }^{33-35}$

The correlation between the visual field sensitivity (in logarithmic scale) and the structural parameters (in linear scale) is stronger in low level of decibel changes (compared with high level of decibel changes). This is observed at least in part of the curvilinear correlations. ${ }^{33}$ Curvilinear regression models (of the second and third order) are the best way to present the relationship between visual field sensitivity and RNFL/GCC thickness as in our study. ${ }^{22,36,37}$ Although curvilinear models are the best fit for our data, the structural parameters could not fully explain the variations of functional losses in advanced glaucoma.

\section{CONCLUSION}

Our results suggest that the nonlinear regression models are more appropriate to assess the correlation between the functional changes (MD) and structural changes (OCT parameters) in advanced glaucoma. The correlations we found in the study were moderate.

\section{REFERENCES}

1. Sommer A, Quigley HA, Robin AL, Miller NR, Katz J, Arkell S. Evaluation of nerve fiber layer assessment. Arch Ophthalmol 1984;102(12):1766-1771.

2. Sommer A, Miller NR, Pollack I, Maumenee AE, George T. The nerve fiber layer in the diagnosis of glaucoma. Arch Ophthalmol 1977;95(12):2149-56.

3. Quigley HA, Miller NR, George T. Clinical evaluation of nerve fiber layer atrophy as an indicator of glaucomatous optic nerve damage. Arch Ophthalmol 1980;98(9):1564 -71.

4. Quigley HA, Dunkelberger GR, Green WR. Retinal ganglion cell atrophy correlated with automated perimetry in human eyes with glaucoma. Am J Ophthalmol 1989;107(5):453- 64.

5. Pederson JE, Anderson DR. The mode of progressive disc cupping in ocular hypertension and glaucoma. Arch Ophthalmol 1980;98(3):490-5.

6. Bowd C, Weinreb RN, Williams JM, Zangwill LM. The retinal nerve fiber layer thickness in ocular hypertensive, normal, and glaucomatous eyes with optical coherence tomography. Arch Ophthalmol 2000;118:22-6.

7. Sommer A, Pollack I, Maumenee AE. Optic disc parameters and onset of glaucomatous field loss. II. Static screening criteria. Arch Ophthalmol 1979;97:1449-54.

8. Sommer A, Pollack I, Maumenee AE. Optic disc parameters and onset of glaucomatous field loss. I. Methods and progressive changes in disc morphology. Arch Ophthalmol 1979;97:1444-8.

9. Sommer A, Katz J, Quigley HA, et al. Clinically detectable nerve fiber atrophy precedes the onset of glaucomatous field loss. Arch Ophthalmol 1991;109:77-83.

10. Harwerth RS, Carter-Dawson L, Shen F, Smith EL 3rd, Crawford ML. Ganglion cell losses underlying visual field defects from experimental glaucoma. Invest Ophthalmol Vis Sci 1999;40:2242-50.

11. Schuman JS, Hee MR, Puliafito CA, et al. Quantification of nerve fiber layer thickness in normal and glaucomatous eyes using optical coherence tomography. Arch Ophthalmol 1995;113:586-96.

12.Heijl A, Patella V. Essential Perimetry: The Field Analyzer Primer. 3. Carl Zeiss Meditec; 2002.

13. Ghadiali Q, Hood DC, Lee C, et al. An analysis of normal variations in retinal nerve fiber layer thickness profiles measured with optical coherence tomography. J Glaucoma 2008;17:333-40.

14.Patella VM. STRATUSOCT: Establishment of Normative Reference Values for Retinal Nerve Fiber Layer Thickness Measurements. Dublin, CA: Carl Zeiss Meditec, Inc; 2003.

15. Budenz DL, Anderson DR, Varma R, et al. Determinants of normal retinal nerve fiber layer thickness measured by Stratus OCT. Ophthalmology 2007;114:1046-52.

16. Harwerth RS, Vilupuru AS, Rangaswamy NV, Smith EL 3rd. The relationship between nerve fiber layer and perimetry measurements. Invest Ophthalmol Vis Sci 2007;48:763-73.

17. Garway-Heath DF, Poinoosawmy D, Fitzke FW, Hitchings RA. Mapping the visual field to the optic disc in normal tension glaucoma eyes. Ophthalmol- 
ogy 2000;107:1809-15.

18. Strouthidis NG, Vinciotti V, Tucker AJ, Gardiner SK, Crabb DP, Garway-Heath DF. Structure and function in glaucoma: The relationship between a functional visual field map and an anatomic retinal map. Invest Ophthalmol Vis Sci 2006;47:5356-62.

19. Ferreras A, Pablo LE, Garway-Heath DF, Fogagnolo P, Garcia-Feijoo J. Mapping standard automated perimetry to the peripapillary retinal nerve fiber layer in glaucoma. Invest Ophthalmol Vis Sci 2008;49:301825.

20. Kass MA, Heuer DK, Higginbotham EJ, et al. The Ocular Hypertension Treatment Study: a randomized trial determines that topical ocular hypotensive medication delays or prevents the onset of primary open-angle glaucoma. Arch Ophthalmol 2002;120:701-713. discussion 829 -730.

21. Miglior S, Zeyen T, Pfeiffer N, Cunha-Vaz J, Torri V, Adamsons I. Results of the European Glaucoma Prevention Study. Ophthalmology 2005;112:366-75.

22. Kim NR, Lee ES, Seong GJ, Kim JH, An HG, Kim CY. Structure -Function Relationship and Diagnostic Value of Macular Ganglion Cell Complex Measurement Using Fourier-Domain OCT in Glaucoma. Invest Ophthalmol Vis Sci 2010;51(9):4646-51.

23. Tan O, Chopra V, Lu AT, et al. Detection of macular ganglion cell loss in glaucoma by Fourier-domain optical coherence tomography. Ophthalmology 2009;116(12):2305-14.

24.Leung CK, Chong KK, Chan WM, et al. Comparative study of retinal nerve fiber layer measurement by StratusOCT and GDx VCC, II: structure/function regression analysis in glaucoma. Invest Ophthalmol Vis Sci 2005;46(10):3702-11.

25.Hood DC. Relating retinal nerve fiber thickness to behavioral sensitivity in patients with glaucoma: application of a linear model. J Opt Soc Am A Opt Image Sci Vis 2007;24:1426-30.

26.Hood DC, Kardon RH. A framework for comparing structural and functional measures of glaucomatous damage. Prog Retin Eye Res 2007;26: 688-710.

27.Hood DC, Anderson SC, Wall M, Kardon RH. Structure versus function in glaucoma: an application of a linear model. Invest Ophthalmol Vis Sci
2007;48:3662-8.

28. El Beltagi TA, Bowd C, Boden C, et al. Retinal nerve fiber layer thickness measured with optical coherence tomography is related to visual function in glaucomatous eyes. Ophthalmology 2003;110:2185-91.

29. Bowd C, Zangwill LM, Medeiros FA, et al. Structurefunction relationships using confocal scanning laser ophthalmoscopy, optical coherence tomography, and scanning laser polarimetry. Invest Ophthalmol Vis Sci 2006;47:2889-95.

30. Harwerth RS, Wheat JL. Modeling the effects of aging on retinal ganglion cell density and nerve fiber layer thickness. Graefes Arch Clin Exp Ophthalmol 2008;246:305-14.

31. Harwerth RS, Wheat JL, Rangaswamy NV. AgeRelated Losses of Retinal Ganglion Cells and Axons. Invest Ophthalmol Vis Sci 2008;49(10):4437-43.

32. Wheat JL, NV Rangaswamy, RS Harwerth. Correlating RNFL Thickness by OCT with Perimetric Sensitivity in Glaucoma Patients. J Glaucoma 2012;21(2):95-101.

33. Garway-Heath DF, Caprioli J, Fitzke FW, Hitchings RA. Scaling the hill of vision: the physiological relationship between light sensitivity and ganglion cell numbers. Invest Ophthalmol Vis Sci 2000;41:1774-82.

34. Garway-Heath DF, Holder GE, Fitzke FW, Hitchings RA. Relationship between electrophysiological, psychophysical, and anatomical measurements in glaucoma. Invest Ophthalmol Vis Sci 2002;43:2213-20.

35. Swanson WH, Felius J, Pan F. Perimetric defects and ganglion cell damage: interpreting linear relations using a two-stage neural model. Invest Ophthalmol Vis Sci 2004;45:466-72.

36. Leung CK, Medeiros FA, Zangwill LM, et al. American Chinese glaucoma imaging study: a comparison of the optic disc and retinal nerve fiber layer in detecting glaucomatous damage. Invest Ophthalmol Vis Sci 2007;48(6):2644-52.

37. Schlottmann PG, De Cilla S, Greenfield DS, Caprioli J, Garway- Heath DF. Relationship between visual field sensitivity and retinal nerve fiber layer thickness as measured by scanning laser polarimetry. Invest Ophthalmol Vis Sci 2004;45(6):1823-9. 


\title{
Связь между изменениями полей зрения и результатами оптической когерентной томографии при открытоугольной глаукоме в развитой стадии
}

\author{
Снежина С. Костянева ${ }^{1,2}$, Мариэта И. Конарева-Костянева ${ }^{1,2}$, Марин А. Атанасов ${ }^{1,2}$ \\ 1,2 Кафедра глазных болезней, Медицинский факультет, Пловдивский медицинский университет, Пловдив, Болгария \\ ${ }^{2}$ Клиника глазных болезней, Университетская многопрофильная больница активного лечения "Св. Георги", Пловдив, \\ Болгария
}

\section{Для корреспонденции: Снежина Костянева, докторант и практикант \\ Кафедра глазных болезней, Медицинский факультет, Пловдивский медицинский университет, Пловдив, Болгария E-mail: snezhina_sk@abv.bg Tel.: +359882253337;}

Дата получения: 27.03.2016 г. Дата приемки: 05.07.2016 г. Дата онлайн публикации: 08.08.2016 г.

Дата публикации: 30.09.2016 г.

Ключевые слова: глаукома с открытым углом, поле зрения, оптическая когерентная томография

Цитаты: Костянева С.С., Конарева-Костянева М.И., Атанасов М.А. Связь между изменениями полей зрения и измерениями с помощью оптической когерентной томографии при открытоугольной глаукоме в развитой стадии.

Журнал "Folia Medica" 2016;58(3);174-181 doi: 10.1515/folmed-2016-0027
Цель: Оценка связи между функциональными изменениями полей зрения и структурными изменениями при открытоугольной глаукоме в развитой стадии (OAG), установленной с помощью спектральной оптической когерентной томографии (SD-OCT).

Методы: В данное исследование был включен анализ состояния 31 глаза в группе из 25 пациентов с ОАG. Помимо рутинного осмотра глаз, с пациентами была проведена стандартная автоматическая периметрия - анализатор поля зрения "Хемфри" и SD-OCT (RTVue-100) в течение 6 месяцев. Глобальные периметрические индексы исследуемой группы составили: среднее отклоне-

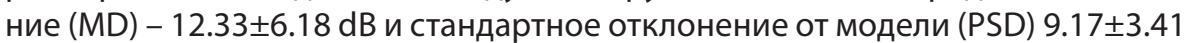
$\mathrm{dB}$. Связь между результатами ОСТ и MD и PSD была выявлена с помощью корреляционного (коэффициент корреляции Пирсона) и регрессионного (модель линейной и нелинейной регрессии) анализа.

Результат: Измерение толщины нижней половины комплекса ганглиозных клеток (GCC) и слоя нервных волокон сетчатки (RNFL) с помощью двух протоколов сканирования (ONH и 3.45) показало, что они тоньше верхней половины, однако разница не является статистически важной величиной. Корреляция между глобальными индексами MD/PSD и большинством проанализированных количественных ОСТ измерений была умеренной ( $\mathrm{r}$ в диапазоне от 0.3 до 0.6). Соотношение между MD и GCC выявило нелинейную кубическую регрессию ( $R 2=0.417, \mathrm{P}=0.004)$. Была установлена хорошая корреляция между $M D$ и $G L V(R 2=0.383 ; P=0.008)$. Линейная регрессия (с $\mathrm{P}<0.05)$ была выявлена только между MD и зоной глазницы (R2=0.383; $\mathrm{P}=0.008)$ и между MD и RNFL с протоколом 3.45 ( $R 2=0.131, \mathrm{P}=0.045)$.

Заключение: Оказалось, что модели нелинейной регрессии больше подходят для оценки связи между функциональными и структурными изменениями глаз с глаукомой в развитой стадии. Выявленные нами взаимосвязи являются незначительными. 